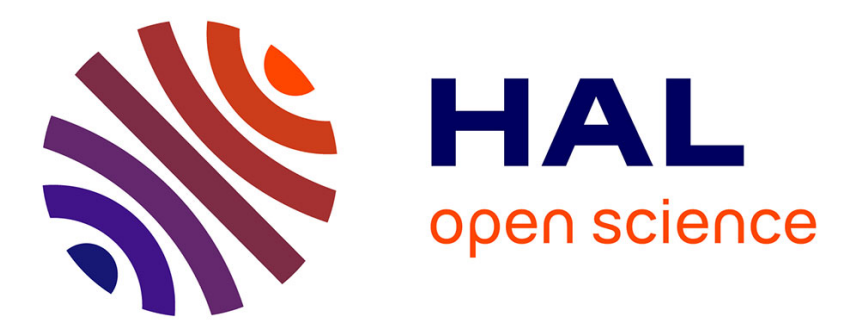

\title{
Knowledge description for the suitability requirements of different geographical regions for growing wine
}

Bernard Kamsu-Foguem, Aurélie Flammang

\section{To cite this version:}

Bernard Kamsu-Foguem, Aurélie Flammang. Knowledge description for the suitability requirements of different geographical regions for growing wine. Land Use Policy, 2014, vol. 38, pp. 719-731. 10.1016/j.landusepol.2014.01.018 . hal-01005512

\section{HAL Id: hal-01005512 \\ https://hal.science/hal-01005512}

Submitted on 13 Jun 2014

HAL is a multi-disciplinary open access archive for the deposit and dissemination of scientific research documents, whether they are published or not. The documents may come from teaching and research institutions in France or abroad, or from public or private research centers.
L'archive ouverte pluridisciplinaire HAL, est destinée au dépôt et à la diffusion de documents scientifiques de niveau recherche, publiés ou non, émanant des établissements d'enseignement et de recherche français ou étrangers, des laboratoires publics ou privés. 


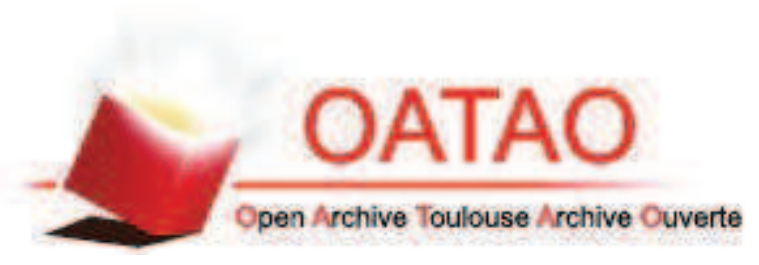

\section{Open Archive Toulouse Archive Ouverte (OATAO)}

OATAO is an open access repository that collects the work of Toulouse researchers and makes it freely available over the web where possible.

This is an author-deposited version published in: http://oatao.univ-toulouse.fr/ Eprints ID: 11387

To link to this article : DOI:10.1016/j.landusepol.2014.01.018

http://dx.doi.org/10.1016/j.landusepol.2014.01.018

\section{To cite this version:}

Kamsu-Foguem, Bernard and Flammang, Aurélie Knowledge description for the suitabilitt requirements of different geographical regions for growing wine. (2014) Land Use Policy, vol. 38. pp. 719-731. ISSN 02648377.

Any correspondence concerning this service should be sent to the repository administrator: staff-oatao@,listes-diff.inp-toulouse.fr 


\title{
Knowledge description for the suitability requirements of different geographical regions for growing wine
}

\author{
Bernard Kamsu-Foguem ${ }^{\mathrm{a}, *}$, Aurélie Flammang ${ }^{\mathrm{b}}$ \\ ${ }^{a}$ Laboratory of Production Engineering (LGP), EA 1905, ENIT-INPT University of Toulouse, 47 Avenue d'Azereix, BP 1629, 65016, Tarbes Cedex, France \\ ${ }^{\mathrm{b}}$ Wines and Plus: 10 rue René Huet, 51100 Reims, 5 France
}

Keywords:

Knowledge modeling

Rules formalization

Conceptual graphs

Information analysis

Viticulture

China
A B S T R A C T

The production of wine has progressed on every main continent. The knowledge modeling can support the sharing of expertise, methods and good practice concerning international grape vine growing and wine production while maintaining a high level of quality. Our research focuses specifically on the development of a support system for knowledge formalization. We describe some procedural rules to represent experienced knowledge in the viticulture domain and plant pathology. We use a graphical software for rules management. The visual representation is a step toward the improvements of interaction between Artificial Intelligence methods and domain experts to make interpretable learning models for concrete decisions. This implementation enables us to make valuable visual reasoning to search whether the Chinese regions are capable of receiving a production of French vineyards. In particular, one outcome is that two Chinese regions appear more favorable and consistent for the development of wine from the Bordeaux region.

\section{Introduction}

The practice of grape cultivation and fermentation to produce wine is the part of Eastern and Mediterranean civilizations. The production of wine has progressed into a greatly structured scientifically detailed process that yields outstanding wines on every main continent around the world (Luca, 2011). Culture of wines is the part of French heritage and is synonymous with quality in the world (Charters, 2006). Here we seek to support the export of know-how, methods and good practice concerning international grape vine growing and wine production while maintaining a high level of quality. Many varieties of wine have been made over the millennia and there is a comprehensive assortment of particular and typical wine styles (Jackson, 2000). Wine is sometimes associated with health promoting properties. Some molecules (e.g. resveratrol, hydroxytyrosol and melatonin) naturally present in wine have showed antioxidant, cardioprotective, anticancer, antidiabetic, neuroprotective and antiaging activities (Fernández-Mar et al., 2012). These health benefits and social media have some influences on consumer behavior in emerging markets (e.g. sustainable/organic wines) (Lockshin and Corsi, 2012). However, numerous consumers drink mainly wine for enjoyment of the flavors. Wine tourism also has a significant role

\footnotetext{
* Corresponding author. Tel.: +33 624302337; fax: +33 0562442708.

E-mail address: Bernard.Kamsu-Foguem@enit.fr (B. Kamsu-Foguem).
}

in inter-continental relationship marketing chain (Hojman and Hunter-Jones, 2012.)

The quality of wines demanded by consumers is on the increase and this is becoming a major concern for winemakers and grapevine growers all around the world. The notion of wine-growing area represents the best combination of 'soil-climate-vine', respecting the possibilities for resources and services supplied by the natural environment. The wine grower expertise is transformed into association rules covering a wide range of factors relating to the full development of a vineyard from site selection to successful vine growing and they are: in a specific geographical location and under specific human actions, regional climate or microclimate, the chemical and physical parameters of the target soil with its water at field scale. The advances in technology and research give us the directions to follow: factors associated with "terroirs", which have the greatest influences on the quality of the grapes and, therefore, the quality and specificities of the wine.

We focus on this project to study an implementation project of French wines on Chinese territory. It is essential to judge the relevance of the grape production in Asia. The purpose of our researches focuses specifically on the development of a support system for decision-making. Indeed we see that the actors of the wineries do not effectively use all available information for decision making. In order to obtain a good product for a good wine, we focused on how the quality of grapes could be improved for producing refined premium wine labels. 
In our study, we sought to address the following issues:

- Is it possible to plant vineyards with vines of European type in China? The climatic and geological conditions in China are they similar or compatible with European varieties? We examined the adaptability of China's potential wine growing areas under different climate regimes, with a view to describing the common features of adaptive viticulture-making? Are these areas more likely to be developed into vineyards/more suitable for grapevine growing when compared with other regions? Analyze the criteria based on which the currently developed Chinese vineyard sites were chosen and developed and where they are located?

- Potential vineyards will they be able to meet the requirements: quality, legislative, environmental exigencies of local or global market?

- What are the exact conditions that make European and Chinese vineyards similar? Are they the same expectations on the local Chinese market and the world market?

- What are the factors reflected by the identified parameters that show similarities, and on which ones we should act?

- What are the intrinsic and extrinsic factors in grapevine growing the wine production? How climate and geology factors affect the development of the vine? Is it possible to promote biological treatment? And to what extent can we meaningfully formalize the domain knowledge? To what extent can we possibly draw generalizations on other practices' approach to viticulture without running the risk of misunderstanding and misrepresenting others?

We seek to formalize knowledge in order to be more easily transmitted to future growers, whether European or Chinese. We sought a relation between various factors and the proper development of the vine, it emerged that these links were not clearly established at this time and that winemakers acted mainly by application and transmission of know-how and experience.

\section{State of the art: key factors in the vineyards domain}

The vineyard location and planting choices (e.g. vine variety) have the biggest impact on reducing vulnerability, and may also provide considerable adaptive capacity to enhance agricultural resilience to climate change (Nicholas and Durham, 2012). For instance, adaptive strategies have allowed buffering climatic effects on grapevine performances in certain Mediterranean areas (Ripoche et al., 2011).

The literature first presents the different stages of development of the vine, the main vine diseases such as blight, botrytis (gray mold) or mildew and few treatments. It was learned that the diseases do not address all the same parts of the vine (leaves, vines or seeds), they are dependent on seasons and climate, and all varieties are not affected to the same extent. Subsequently, through a study of the different regions of China, we could compare the conditions for the proper development of vineyards. This study focused on the precipitation and the possibility of water areas, as well as sunshine and temperatures in particular through the Huglin index, as we will explain later in this report. We also mentioned varieties implanted in French and Chinese regions. We also analyzed the influence of the soil, its minerals, and climate on the growth of the vine. Finally, we have deepened their study of some French appellations, through three characteristics regions, which are the Loire Valley, Bordeaux and Côtes du Rhone. There are varieties implanted, regional average temperatures and geological features (presence of sand or gravel etc.).

The expertise of the culture of the vine, to try to apply it to parts of China, is not owned by one person but by a group of actors who share their knowledge for the good development of vine and wine production. During our researches we had information from various trades: winemaker, winery technical director, analyst taster or engineer in a laboratory of oenology.

After researching analysis of existing practices we realized that some factors were essential to the development of varieties. Here the main factors on which we based our research and studies are geology, climate, diseases and treatments, driving mode and irrigation.

\section{Geology}

Soil definition: the rock is at the origin of the formation of the basement that we know today. It is characterized by physicochemical alteration over time provided the elements that constitute the ground. Its rocks can be of three types: sedimentary, igneous or metamorphic rocks.

The soil itself has four layers:

- Litter: this layer is closer to the surface which is in direct contact with air. It consists of leaves decaying.

- Humus is the intermediate layer that is composed of organic matter in a state of advanced decomposition. We find the presence of living organisms such as bacteria, unicellular organisms, fungi, etc.

- The mineral layer: it is mainly composed of rock.

- The soil is not inert; it will evolve through the action of microorganisms, insects but also climate (wind, frost, sun, etc.) that will permanently transform its composition.

Indeed, the land on which the grapes grow is going to affect the resistance of varieties, size, etc. On this criterion, several parameters are involved directly. First, the type of soil: the case of limestone, sandstone, clay or another. For example, a clay soil will improve water retention which will prevent the vines suffer water stress (lack of water), while a gravelly soil is rather dry and arid. The soil type is generally related to the following parameters: the content of trace elements and macronutrients (e.g. sandy soil will often be deficient in boron or copper). However, only a scientific analysis of the soil will determine how effectively the soils are rich or poor.

The soil provides all the nutrients and water that the vines need to grow and produce grapes. Nutrients are essential in the life of the vine. They are mostly found in minerals. There are two broad categories, macro-nutrients and micro-nutrients.

\section{Macronutrients:}

- Nitrogen effects elements: it allows the plant to grow for the proper development of the plant;

- Magnesium: it has the same role as nitrogen, but its action is much more specific in the chlorophyll;

- Calcium: it helps nourish the root system of the plant and promotes the rise of sap;

- Potassium: it is a factor of vigor and yield, it facilitates the accumulation of sugars in the grapes, it can also regulate the opening and closing of stomata;

- Phosphorus: it allows root development and ripening berries.

2. Micronutrients:

- Boron: it plays an important role in cell wall structure and formation of grapes and in the metabolism of proteins and carbohydrates. Boron deficiencies occur mostly in alkaline soils or sandy soil.

- Copper: it plays a role in the production of chlorophyll. It may also intervene in the control of certain diseases. Copper deficiency is rare in mineral soils, except in very sandy soils. It involves sensitivity to dehydration. 
- Iron: it is necessary for the formation of chlorophyll in plant respiration and the formation of certain proteins. Factors associated with iron deficiency include high concentrations of lime (and therefore high $\mathrm{pH}$ ), and extreme imbalances with other trace elements such as molybdenum, copper and manganese.

- Manganese: it is involved in photosynthesis and chlorophyll production. It helps to activate enzymes involved in the distribution of growth regulators in the plant. The consequences are shriveled collected clusters of grapes, instead of having normal growth, in the less favorable condition for vegetative growth.

- Molybdenum essential: Element involved in the nitrogen cycle.

- Zinc: it is important in the early stages of growth and in the formation of the grapes. It also plays a role in the production of chlorophyll and carbohydrates. The consequences of its deficiency are blocking of auxin growth with vegetative disorder, risk of nitrogen accumulation with susceptibility to diseases and parasites.

- Microscopic organisms consisting of soil microbial biomass involved including the degradation of organic compounds in mineral uptake by plants. Microbial biomass represents the amount of "living carbon" contained in the soil microbes, mainly bacteria and fungi. There are therefore very important components of the soil.

Micronutrients are minerals necessary for plant life, but in small quantities (a gram per hectare per year). Despite these small amounts assimilated by the vine, the lack or excess of these elements can cause physiological problems (deficiency or toxicity) detrimental to the quality and quantity of harvest but also the sustainability of stocks.

Indeed, trace elements play an important physiological role: photosynthesis, respiration, energy transport, etc. However, these problems are rare and often unique to particular situations (soil type, weather, etc.).

Vines

Several factors affect vines and wine quality. It is clear from several studies that eventually the water supply of the vine is in many cases the quality factor which builds those important taste aspects needed to drive consumer preference. Water regime of a plant involves climate and soil through evapotranspiration; vine absorbs water through the roots and break through the leaves.

At the end of winter, there is a certain amount of water available in the soil: the necessary water stock. This reserve decreases during vegetative growth of the vine due to a by evaporation of sweat but especially by the leaves.

Overall, the presence of water in the soil is favorable to vegetative potential of the vine. If the vine has enough water and light throughout the cycle, it favors growth of vegetatively propagated varieties. Photosynthesis enables plants to produce food for themselves and the vines use its energy for production of leaves and stems, which will predominate over the berries. A water deficit is necessary to make a quality wine. When it occurs, shoots grow and berries stop. Sugars formed by photosynthesis are then available to feed berries. However, if the deficit is too large, the lack of water requires so excessive vine naturally limit water loss. Plant stomata close leaves, limiting or stopping water uptake and gas exchange. The production of sugars is then interrupted at the expense of maturation. It is ideal for a quality production to have a floor that provides a level of water deficit (but not excessive) relatively early to promote the accumulation of sugars.

Soil composition plays a very important role in the water supply of the vine. We distinguish two different soil types, percolation soil that filters rainfall and hydromorphic soil that can drain the water by their inclinations. A good root development of the vine is very important not only to the anchoring of the plant, but also for absorbing water and nutrients.

Deep-rooted of the vines: up to about $60 \mathrm{~cm}$, the roots grow vertically, but as horizontal to capture more nutrients. After $60 \mathrm{~cm}$, rooting is only vertical. It is from $3 \mathrm{~m}$ but up to $10 \mathrm{~m}$ depending on the terrain. On soils with a filter, the plant will need long roots able to seek water from deep below the surface of the earth, making it resistant to draughts triggered by climate change.

A field with good soil is one that produces abundant fruit when seeds are sown and development and selective treatment with herbicides may be warranted to promote the development of compatible plants. But it also requires that the plant can have all the nutrients and trace elements that will be characteristic of the grape. The composition of soil varies from one place to another with its specificities (e.g. river banks, forest, grassy fields, top of a hill, and bottom of a hill). The contribution of ground water is also very important; it must be input even during the period of ripening and grapes with thick skins, are both quality factors.

\section{Climate}

In this factor, we focused on two parameters: temperature and precipitation. The temperature has a direct impact on wine quality both from the perspective of the sugar content and the $\mathrm{pH}$ variation (acidity level). The Huglin index estimates the heliothermal potential of a specific climatic condition; temperature calculations consider the period of the day in which grapevine metabolism is more active (Huglin and Schneider, 1998). The calculated value comprises a correction factor for the length of the day in higher latitudes and is an indicator used to identify if the temperatures are suitable grape varieties (probable sugar content and acidity ratio).

Huglin index is obtained by calculating an index on a year of average daily temperatures above $10^{\circ} \mathrm{C}$, between $1 \mathrm{st}$ April and 30th September. It helps to have an idea of the amount of heat received by the plant during its growing season. It helps to describe the overall climate of a region, or the potential for adaptation of a species (Table 1).

Huglin index is described by the following equation (Tonietto and Carbonneau, 2004):

- For the Northern hemisphere

$$
\mathrm{HI}=\sum_{1 \text { apr }}^{30 \text { sep }} \frac{[(T-10)+(\mathrm{Tx}-10)]}{2} \cdot k
$$

- For the Southern hemisphere

$$
\mathrm{HI}=\sum_{1 \text { oct }}^{30} \frac{[(T-10)+(\mathrm{Tx}-10)]}{2} \cdot k
$$

where $T$ is the mean air temperature $\left({ }^{\circ} \mathrm{C}\right)$; Tx the maximum air temperature $\left({ }^{\circ} \mathrm{C}\right) ; k$ the day length coefficient, varying from 1.02 to 1.06 between $40^{\circ}$ and $50^{\circ}$ latitude.

Regarding precipitation, it is important to know the rainfall periods and the amounts present in each region. Water is an essential element in the development of the vine but can be harmful depending on the period of the life cycle of the vine and the amount of water present. Indeed, humidity favors the development of most diseases and for example in the ripening stage. Water intake too reduces the amount of sugar in the grapes and water supply must be guided by the principles of sustainable development and done in good conditions, primarily during the first part of the vegetative 
Table 1

The average temperatures of regions by seasons.

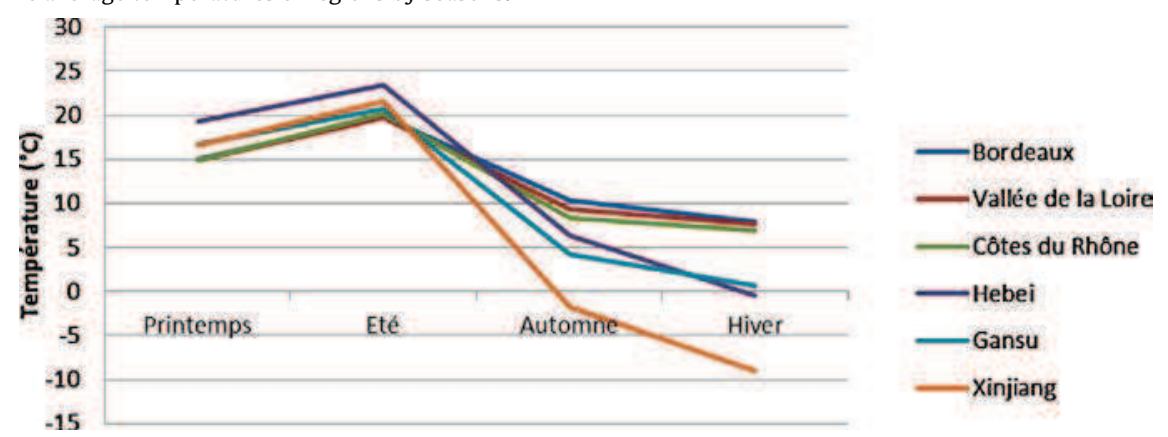

cycle. During maturation, a water regime less restrictive as a more severe stress will reduce the sugar content of the grapes. But the quality of the red wine depends more on its phenolic content than the sugar content at maturity. Enological potential of black grapes can be excellent, even if a strong water stress slightly penalizes the sugar content of the juice.

The sun is another factor that can affect the quality of the grapes. In fact, light is essential for the plant to perform photosynthesis. This process allows plants to synthesize sugars. In the vast majority of the wine regions of the world, the light radiation is sufficient for this phenomenon to occur. The greatest length of daylight in the northern regions compensates the effect of the decrease in the luminous intensity. Having colored soils can help because it will reflect more light and therefore the plant will be exposed. Plenty of sunshine is essential in the previous two months of the harvest because it is at this point that the sugar will accumulate in the grapes.

\section{Diseases and their treatment}

The culture of the vine is a complex art, indeed the vine disease accumulates the most diverse and unexpected effects: mushroom and insects cause whenever significant damage. The agro-environmental research relies increasingly on systemic approaches and computer simulation. There are two objectives to analyze the treatment of the vine (Léger and Naud, 2009):

- The first is to analyze the expected performance of a system according to the criteria of sustainable development.

- The second is to make a transfer of knowledge and expertise through models of decision making.

If we generalize a model for control of diseases, a decision process, we can reduce the number of treatments currently responsible for a high consumption of pesticides by viticulture. The establishment of a decision-making process will reduce the number of treatment compared with usual practice, strongly consuming pesticides. It is therefore important to identify quickly but accurately diseases in the vineyard to prevent infestations and loss of performance or quality. However, it is necessary to emphasize that the presence of a pathogen or disease does not automatically mean that treatment is necessary. Each year the severity of the disease varies, it is mainly due to climatic conditions, the history of the vineyard and the sensitivity of varieties.

We decided to study this criterion because the disease condition the sustainability of the feet, and the quantity of grapes (and therefore wine) produced. Some diseases occur directly on grapes such as botrytis and other feet or vine leaves. Overall, the diseases thrive throughout the year except in winter where they shall be controlled in accordance with the requirements given in the domain knowledge. Some diseases will find it easier to develop on certain varieties or with a certain humidity and temperature. Regarding level of treatment, there are different types of fungicides against fungi, insecticides and herbicides but actually those agronomics methods are far away from an environmental care. The decision to apply a fungicide is based on certain elements such as estimated disease risk, economic threshold, and duration of protective cover provided by fungicides (Ellison et al., 1998).

We have to precise that "to treat the vines" does not mean automatically "chemical treatments", so we prefer the expression "organic treatments". A life underground of mineral fertilizers are substances of mineral origin, produced by the exploitation of natural deposits of phosphate and potash. Compound fertilizer can be simple mixtures. We distinguish between straight fertilizers, containing only one nutrient, and compound fertilizers, which may contain two or three nutrients. The term mineral fertilizer is normalized by reference to their three main components: NPK. Fertilizers can be simple nitrogenous, phosphatic or potassic. Fertilizers are rated binary NP or NK or PK, the ternary NPK. These letters are usually followed by numbers representing the respective proportions of these elements. Industrially produced chemical fertilizers contain a guaranteed minimum quantity of nutrients, and are indicated on the bag. For example, the formula 5-10-5 indicates the percentage of nitrogen $(\mathrm{N})$, phosphorus $(\mathrm{P})$ and potassium $(\mathrm{K})$ present in the fertilizer, which is $5 \% \mathrm{~N}, 10 \%$ and $5 \%$ of $\mathrm{P}_{2} \mathrm{O}_{5} \mathrm{~K}_{2} \mathrm{O}$. The nitrogen supply is expressed as nitrogen $\mathrm{N}$ and is provided as a nitrate $\mathrm{NO}_{3}, \mathrm{NH}_{4}+$ ammonium or urea. Phosphorus is expressed as $\mathrm{P}_{2} \mathrm{O}_{5}$, but it is provided by the calcium phosphate or ammonium. Potassium is expressed as $\mathrm{K}_{2} \mathrm{O}$, but it is provided by chloride, nitrate and potassium sulphate (Table 2 ).

\section{The driving modes}

The driving mode means how the vines are installed and then cut in a vineyard. It depends on the grape variety, climate, and type

Table 2

Examples of fertilizers.

\begin{tabular}{lrrr}
\hline Fertilizer & $\mathrm{N}$ & $\mathrm{P}$ & $\mathrm{K}$ \\
\hline Beef manure & 6 & 1 & 7 \\
Cow manure & 4 & 1 & 4 \\
Horse manure & 6 & 1 & 5 \\
Pork manure & 4 & 1 & 5 \\
Chicken manure & 23 & 10 & 17 \\
Sheep manure & 8 & 1 & 7 \\
Rabbit manure & 24 & 5 & 0.5 \\
Guano manure & 10 & 13 & 2 \\
Feather manure & 80 & 1 & 0 \\
Wood ash & 0 & 1 & 10 \\
Dry blood & 12 & 20 & 1 \\
Bones & 4 & 12 & 0 \\
Dry fish & 9 & 1 & 4 \\
Horn & 12 & & 0 \\
\hline
\end{tabular}


of operation. There are several steps, depending on the season, in the conduct of vines:

- From November to March, when the vine produces neither fruit nor leaf with approaches conducive to the success of agricultural production. Technical schemes mainly focus on controlling the growth of crops and so improving the control of plant and vine growth.

- From March to April the focus is on maintaining and ordering tools that support the vines, they are essentially used for tying up vines and maintaining plots. This is also the moment when one removes dead steams replaces them with new grape vines as well.

- In May, it is time to make a weed adapted and a rigorous suckering; and next comes the removal of excess branches to suppress the non-fruit bearing young shots.

- From June to mid-August, when the clusters grow, we must clarify the stem by removing clusters and redundant branches, trim the ends of branches preserved, mow between the rows, and start treatments or cleaning operations. It allows controlling the performance and reducing the risk of diseases and the use of chemicals. This can influence the aroma compounds of wines by introducing floral, fruity and spicy nuances (González-Álvarez et al., 2012).

- The period from the end of August to mid-October is the harvest.

- From the end of the harvest until November, there is no work to be done.

Although several factors must be considered in the choice of varieties, such as planting vines less susceptible to disease is a good way to prevent them. The row orientation north-south and the use of the natural slope promote air circulation and drainage. Tillage practices that enhance soil drainage generally reduce the incidence of seedling diseases. Some of them are suitable for restoring the structure of the soil and burying any crop residues by means of plowing, digging over, hoeing or grubbing. A good size facilitates air circulation, which promotes rapid drying of foliage and greater penetration of the fungicide in the crop canopy. In addition, it is recommended to systematically inspect the vineyard throughout the growing season to monitor the onset and progression of various diseases. At the time of harvest and at the end of the season, it is essential to consider the presence of diseases such as powdery mildew, downy mildew and anthracnose. This means that any sanitation practice (e.g. a two-year rotation) or treatment that will reduce the stage of the infections will directly reduce the risk of diseases. The timing of harvest is possibly the most significant viticultural decision taken each season as the characteristics of the fruit when harvested set limits on the latent quality of the wine produced (Jackson, 2000).

\section{Irrigation}

Deficit irrigation in water-stressed conditions, complementary irrigation and water harvesting to deal with the variability of resource availability are some options at field scale for organizing water management. Mastered irrigation increases the yield of a vineyard of $30 \%$ on average and by up to $50 \%$. It does not solve the basic problems but offset a loss due to climatic factors. It will have adverse effects such as advanced maturity of the grapes, and of course empty part of the water supply in the region. That is why we must master these situations.

Changes in the climate and minor rises in temperature have a direct impact on precipitation. There is a very important difference is an order of magnitude between Chinese and French parts (e.g. between regions of Xinjiang and Bordeaux) on precipitation (rain and snow), flow discharge and erosion, temperature and daylight data. The crops suffer in drought conditions that could have an important impact on viticulture operations, beyond the influence of changes in average productivity.

More sandy clay soils are very permeable and does not hold water. To exploit the vine in this region, farmers will have to imperatively irrigate the vines. The advantage of this method is to have a controlled water supply and therefore can control the amount of sugar in the grapes and its acidity. In France irrigation is banned since the 1900 s to prevent abuse. In the 1880 s, wine makers irrigated vines heavily to increase productivity. At the same time, the wine was light and slightly sweet. Using water for irrigation is necessary to maintain vineyards in California, Argentina, Australia and New Zealand. In addition, the proper collection and disposal of process wastewater can be used in the vineyard irrigation with protection of the environment.

\section{Experienced knowledge formalization}

We then established rules of type "algorithmic" that govern the development of the vineyards. They specify the actions prohibited and those which are authorized; that is to say when it is better not to implement, or when one needs to invest in protections or equipment. Artificial Intelligence methods are useful in the modeling approach of agriculture transformations, while the resulting model can be understood by both humans and machines (Papadimitriou, 2012).

In the viticulture domain and plant pathology, it is possible to represent knowledge of the expertise in a series of IF-THEN rules (Ellison et al., 1998). There are some specific procedural rules adapted to the specific needs of the viticulture world. These rules promote power and information sharing among and between participants and decision makers. The structure of this particular analysis therefore adopts a format of IF-THEN rules, concentrating on the procedural rules specified according to climate, geological, disease and treatment factors.

Rules for the climate factor

- IF period = veraison (the beginning of ripening, when the grapes begin to change color from mid-July to August) THEN irrigate regularly within the limits of the law

- IF period = maturation $($ September-mid-October $)$ THEN allow to dry

- IF period $=$ spring AND precipitations $<$ normal value THEN water the crops regularly

- IF Huglin index is outside normal values ( $<1000$ OR $>2500)$ THEN inappropriate region

- IF precipitations $<$ minimum threshold THEN irrigation is possible

Rules for geological factor

- WHILE the nitrogen rate macronutrients, magnesium ( $<15)$, calcium, potassium $(<300)$ AND soil phosphorus $<$ rate necessary for the proper development of the vine THEN enrich the soil

- IF alkaline soil OR sandy soil THEN enrich the soil with boron

- IF sandy soil THEN enrich the soil with copper

- WHILE levels of iron, manganese, molybdenum and zinc $<$ rate necessary for the proper development of the vine THEN enrich the soil

- WHILE pH is outside normal value (not neutral) THEN the proper $\mathrm{pH}$ balance is essential

Rules for the disease factor

- WHILE $\mathrm{SO}_{2}<$ biological value THEN add $\mathrm{SO}_{2}$

- IF organic wine THEN organic processing THEN low yield and need more treatment, within the limit of the quantities determined in the supply balance. 
$\underline{\text { Rules for treatment }}$

IF any of the following conditions is fulfilled:

- In late autumn (preventive treatment against powdery mildew)

- End of winter (preventive treatment against Anthracnose)

- In early spring (preventive treatment against powdery mildew)

- Late spring/summer (after flowering and during veraison) (treatment against mildew)

THEN the use of Bordeaux mixture is recommended OR the use of sulfur for small areas.

Some seasonal treatments are used as:

- IF Autumn THEN use of fertilizer fund as compost

- IF Late winter THEN use of Nettle \& Verbena dry mixed spray

- IF Spring THEN use of Bordeaux mixture (composed of copper sulfate and lime)

Rules with a combination of factors

- IF period = fall AND rain THEN protection and coverage of crops

- IF period = summer AND rain THEN treatment

- IF a designation is equated with Bordeaux AND gravelly calcareous clay soil AND Huglin index $=1830$ THEN accepted name; IF Huglin index $=2050$ THEN Good conditions to the vine-growing cycle.

- IF a designation is equated with Loire Valley AND shale-claysandstone-limestone AND Huglin index $=1500$ THEN designation accepted, IF Huglin index $=1800$ THEN Good conditions to the vine-growing cycle.

- IF Côte du Rhône appellation assimilated AND clay-sand-gravel soil AND Huglin index $=1050$ THEN designation accepted. IF Huglin index $=1850$ THEN Good conditions to the vine-growing cycle.

- IF Period = between April and October AND IF $15^{\circ} \mathrm{C}<$ Temperature $<20^{\circ} \mathrm{C}$ and Precipitations $>10 \mathrm{~mm}$ THEN conditions of mildew development.
- IF Period between March and August AND IF Temperature $\approx 25^{\circ} \mathrm{C}$ AND Precipitations $\approx 0 \mathrm{~mm}$ THEN there are favorable conditions for White powdery mildew development.

- IF Period between April and June AND $10^{\circ} \mathrm{C}<$ Temperature $<35^{\circ} \mathrm{C}$ AND high humidity

THEN there are favorable conditions for Anthracnose development.

- IF Period=between June and October AND IF $18^{\circ} \mathrm{C}<$ Temperature $<20^{\circ} \mathrm{C}$ AND high humidity THEN there are favorable conditions for the development of Botrytis in the grape crops.

\section{Conceptual graphs knowledge representation}

A conceptual graph is a graph with two kinds of nodes respectively called concepts and conceptual relations and each arc must connect a conceptual relation to a concept (it is said that the graph is bipartite) (Sowa, 1984). Visual reasoning is performed through graph homomorphism which maps adjacent nodes to adjacent nodes and offers the possibilities of specialization of the concept and relation nodes labels (Sowa, 2000). As the saying goes "a picture is worth a thousand words", the visual reasoning by means of conceptual graph operations is a magnificent view for the scientific popularization of logical reasoning. Without ruling out the demonstrations by the logical formulas, graph operations are sufficient to explain the visual reasoning process like a diagram that could serve as proof of graphical demonstrations (Chein and Mugnier, 2008).

Once the "algorithmic" rules were established, we need to analyze regions. For this we decided to implement these rules by using software tool called Conceptual Graphical User Interface (CoGui) (Carloni et al., 2009). CoGui is graphic design software developed in Java language. This software allows, from a conceptual graph to

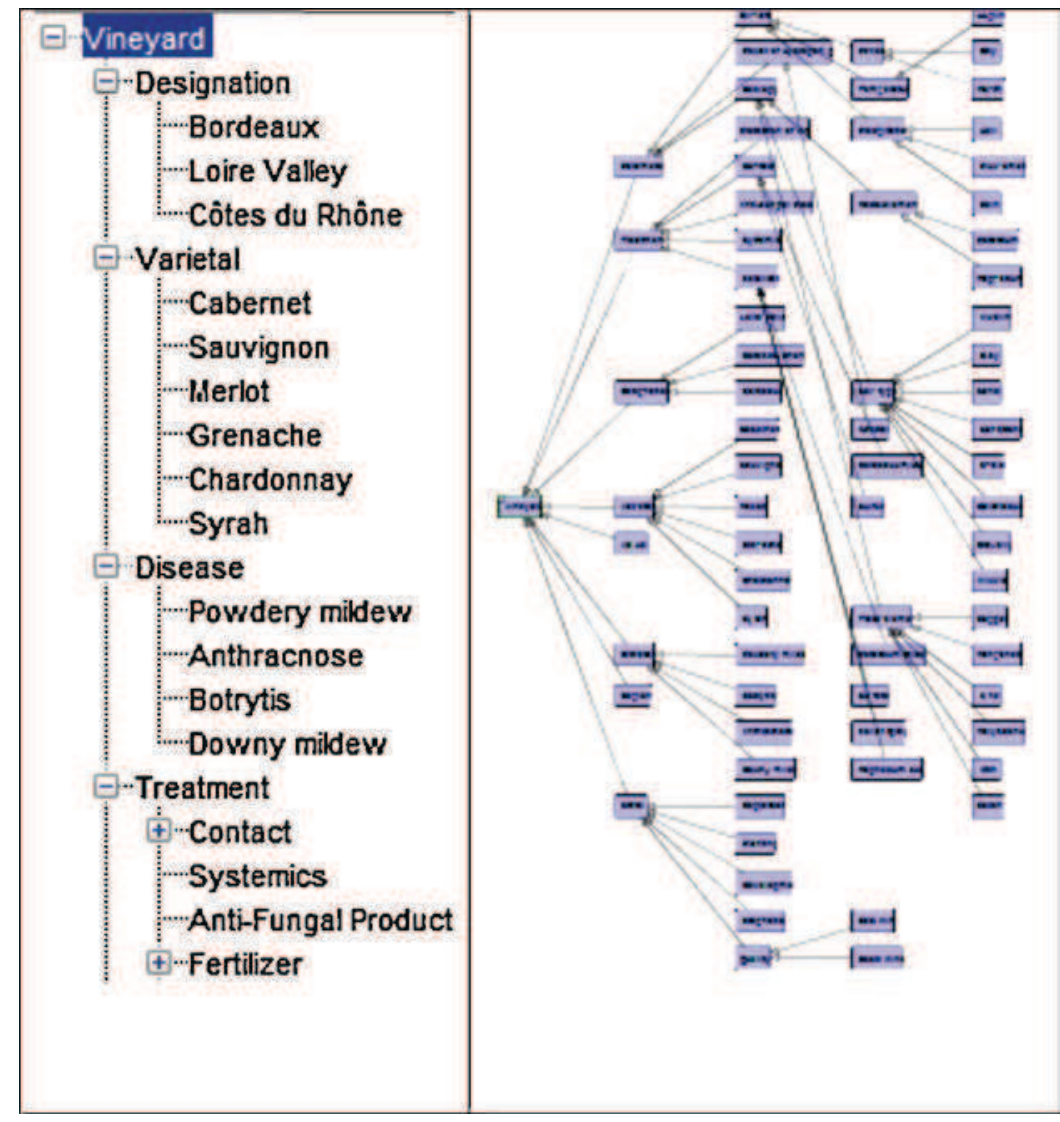

Fig. 1. Partial hierarchy of concepts in the vineyard (tree view and graph view). 
establish a link between the different parameters, it is then possible to build some control rules in a visual form with conceptual graphs. We can then ask a new structure to analyze and compare the prefilled control rules. The software will then investigate whether the structure has similarities with the control rules, and it is possible to draw a conclusion (Genest and Chein, 2005).

This software seems to fit our need, indeed as we have "algorithmic" rules and we can search whether the Chinese regions are capable of receiving a production of French vineyards. We therefore simply enter our control rules as means by which the conceptual graph operations will assist the efforts to make visual reasoning for the analysis of Chinese regions.

Note that the software is only an aid to improve the speed comparisons taking into account all technical, operational and environmental constraints. It advocates the use of graph operations (mainly rules application and constraints verification) to analyze a set of facts (Baget et al., 2011). So, it has the ability to select some graphical representation and therefore highlight relationships that could not be true in a series of charts (Kamsu-Foguem et al., 2013c). In addition the engaged visual reasoning would challenge the relevance, redundancy or inconsistency of described rules (Kamsu-Foguem, 2012). However, this remains the responsibility of the knowledge engineer for whom it is important to be successful and as faithful as possible to the reality in the study and drafting the rules that will control.

\section{First step: construction of domain vocabulary}

At this stage, we describe all information on the characteristics of the studied object (here vineyards), and the domain vocabulary is organized hierarchically in a taxonomy part of a domain ontology (Kamsu-Foguem et al., 2008).

In our case, we started by descriptions of designations (Bordeaux, Loire Valley and Côtes du Rhône) that have some influences on the vineyard. Our aim is to tell if it is possible to associate a
Chinese wine at one of these designations. One has to get this setting for the software to recognize the properties on conditions that determine the character of the wine and its variety.

We then entered different types of vines, because as discussed earlier in this report, some of them directly concern some types of wines. We focused on the following six: Grenache, Chardonnay, Merlot, Syrah, Cabernet and Sauvignon.

We also provide related information about some types of diseases and treatments. We have given information about mildew, anthracnose, botrytis and powdery mildew. For treatments there are several categories, systemic treatment, by contact processing or with fungal products. We also filled some fertilizers, geological parameters (soil types, micronutrients and macronutrients, $\mathrm{pH}$ ), climatic parameters (precipitations, Huglin index) and the periods of the year (Fig. 1).

Similarly it is also vital to comprehend the overall context, to incorporate the different relationships that could then be used to link the parameters between them. We identify three types of relations: usual, temporal and logic (Kamsu-Foguem et al., 2013a) (Fig. 2).

We recorded various data necessary for the study such as months or temperature values, the data will then be used in the comparison tests. They are directly related to the conceptual tree and describe the specific wine-growing characteristics (e.g. thermal requirements). Some fusion methods analyze the spatial relevancy of the information elements of any application region to describe and manage spatial knowledge (Paoli et al., 2007) (Table 3).

\section{Second step: rules representation by conceptual graphs}

In the corresponding template (associated tab in edition mode), we use both graphs and numerical data, previously filled to connect them to build different kinds of conceptual graphs (rules and facts). The rules are divided into two parts: a hypothesis and part accordingly (Baget and Mugnier, 2002). We must

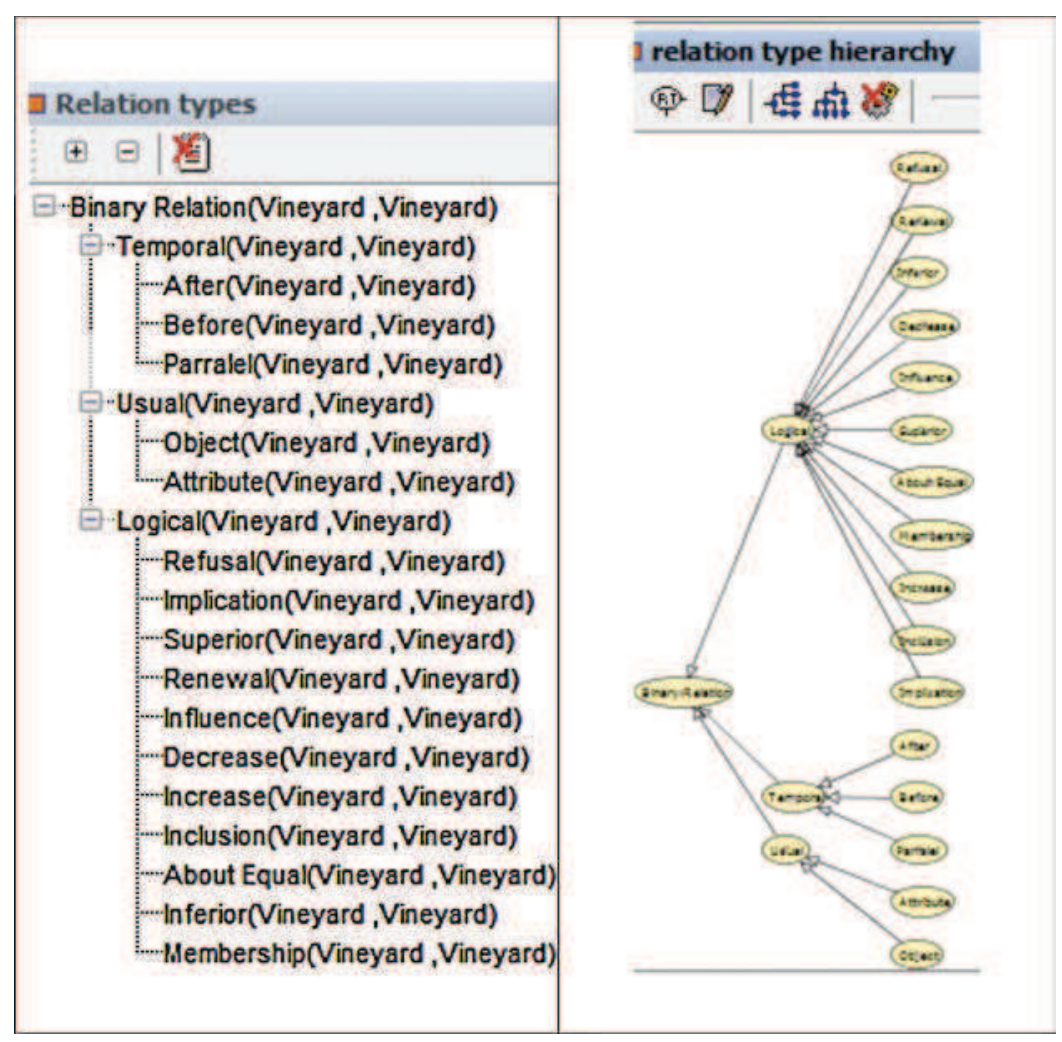

Fig. 2. Hierarchy of conceptual relations (tree view and graph view). 


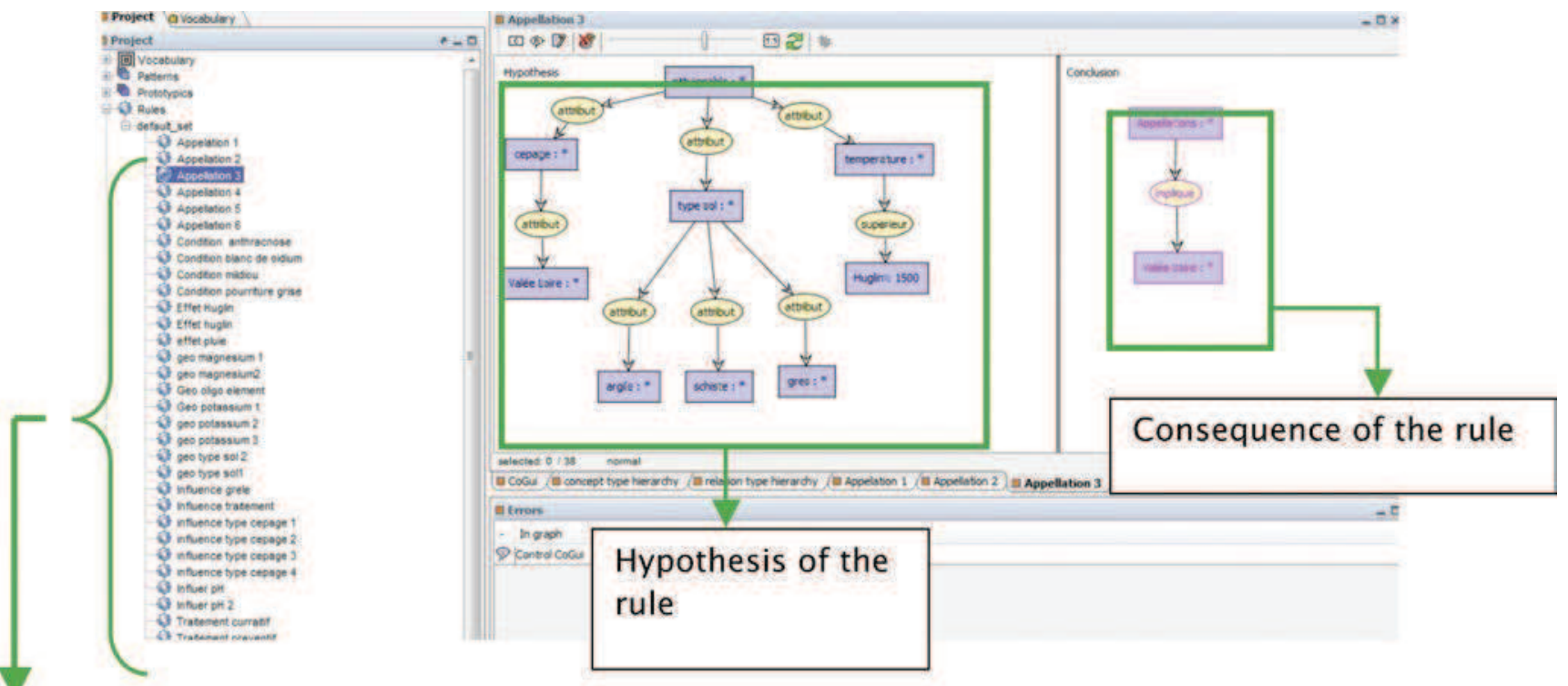

Set of rules

Fig. 3. Screenshot of the interface of the graph rules in the software CoGui.

Table 3

Numerical data of Huglin index.

\begin{tabular}{ll}
\hline Individuals & \\
\hline Name & Privileged type \\
\hline 2500 & Huglin \\
3000 & Huglin \\
1800 & Huglin \\
2000 & Huglin \\
1500 & Huglin \\
\hline
\end{tabular}

understand that if our structure to be analyzed is composed with some facts then the reasoning is focused on verifying hypotheses, whereas procedure analysis mostly involves assessing conditions that are possible to verify by conceptual graph operations. This would allow for revisions of the knowledge and modifications or corrections of the existing contextual viticulture management practices (Figs. 3-6).

\section{Analysis of structural knowledge}

We now enter the graphical structures to analyze the tab "fact". It is enough merely to undertake some visual comparisons with conceptual graphs. It is sufficient to make entries in the appropriate templates and we just proceed in the same way as for the instruction of rules. However, here there is obviously not yet the result in consequence part because it is information that we seek to determine (Fig. 7).

Here we must pass through "reasoning" mode of the software and ask him to analyze the "facts" by comparison with the "control

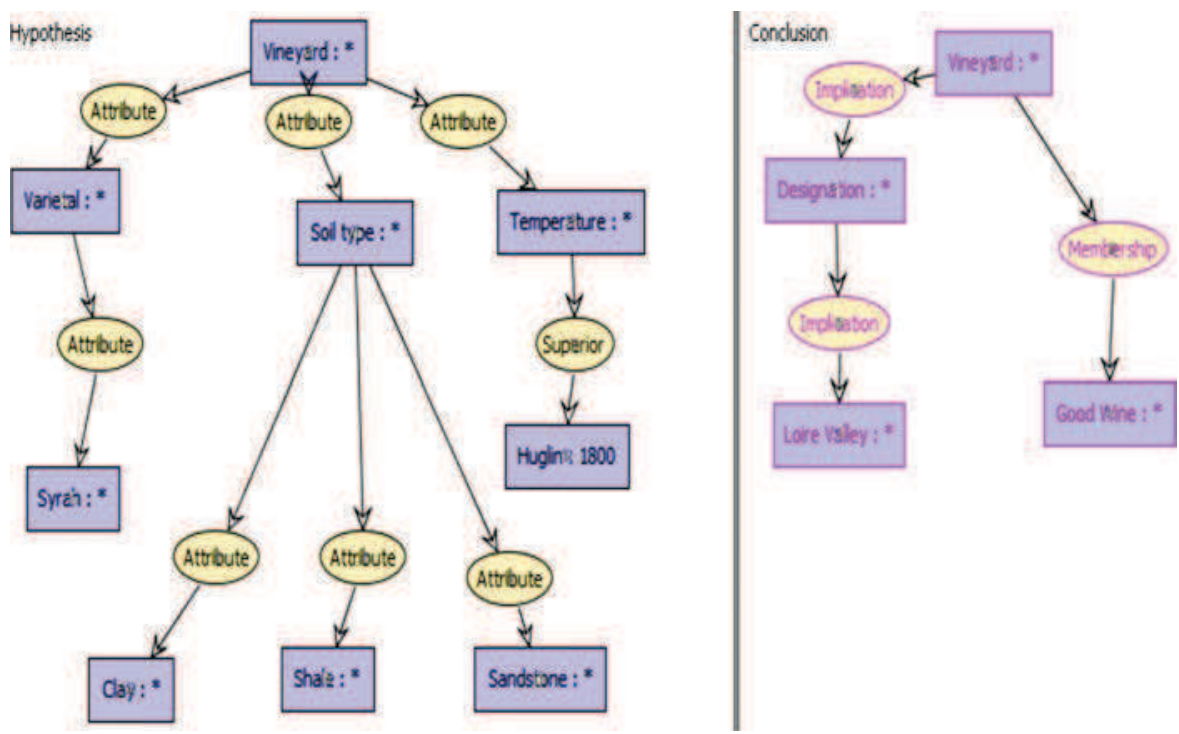

Fig. 4. Example of rule - Here France's Loire Valley designation. 

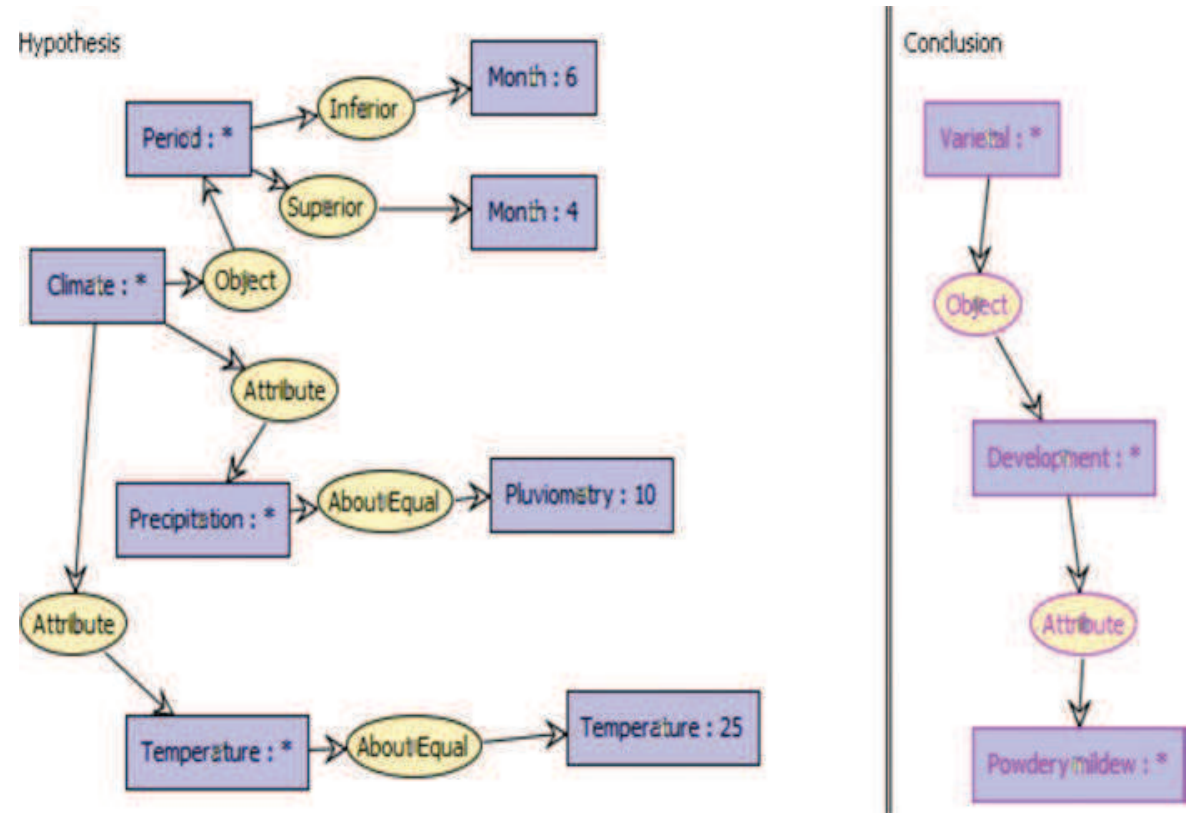

Fig. 5. Example of rule - Here a fungal disease (Powdery mildew).

Hypothesis

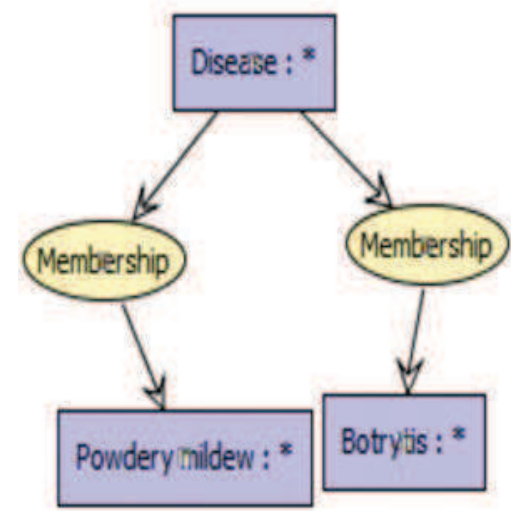

Condusion

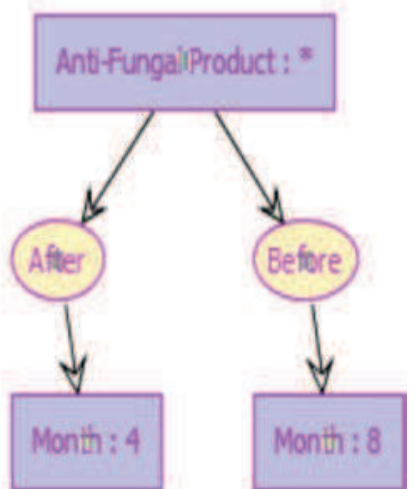

Fig. 6. Example of rule - Here a preventive treatment.
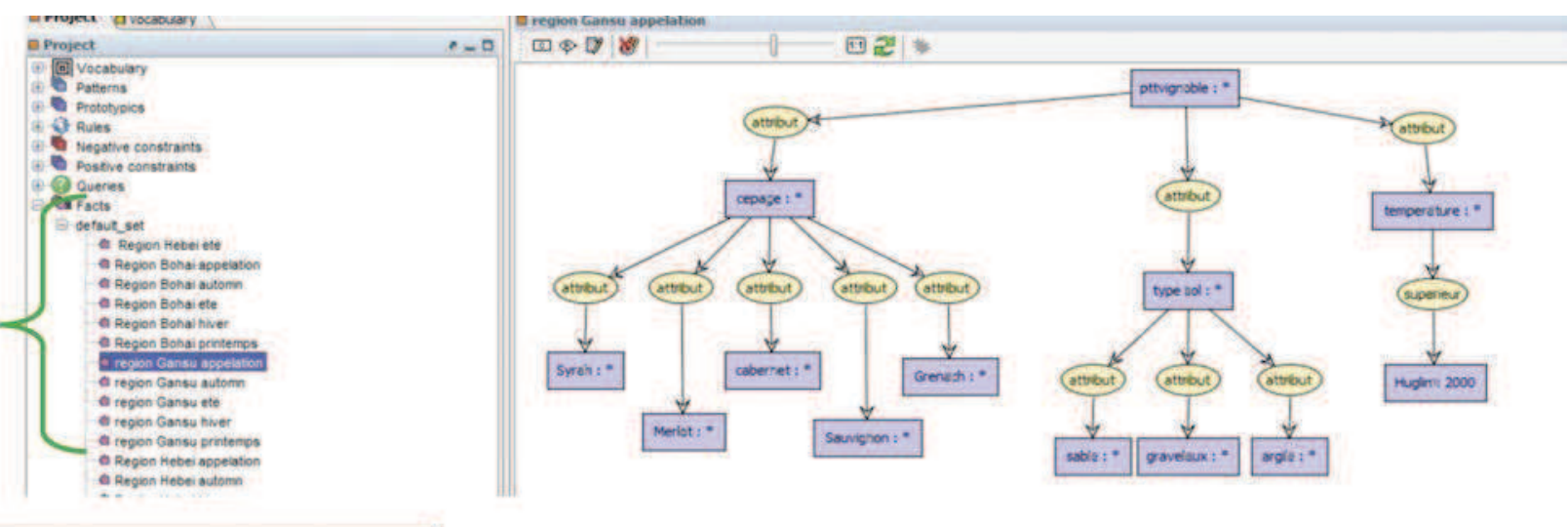

Set of facts to be analyzed

Fig. 7. The situations to be analyzed of their effectiveness - Here Bohai region. 


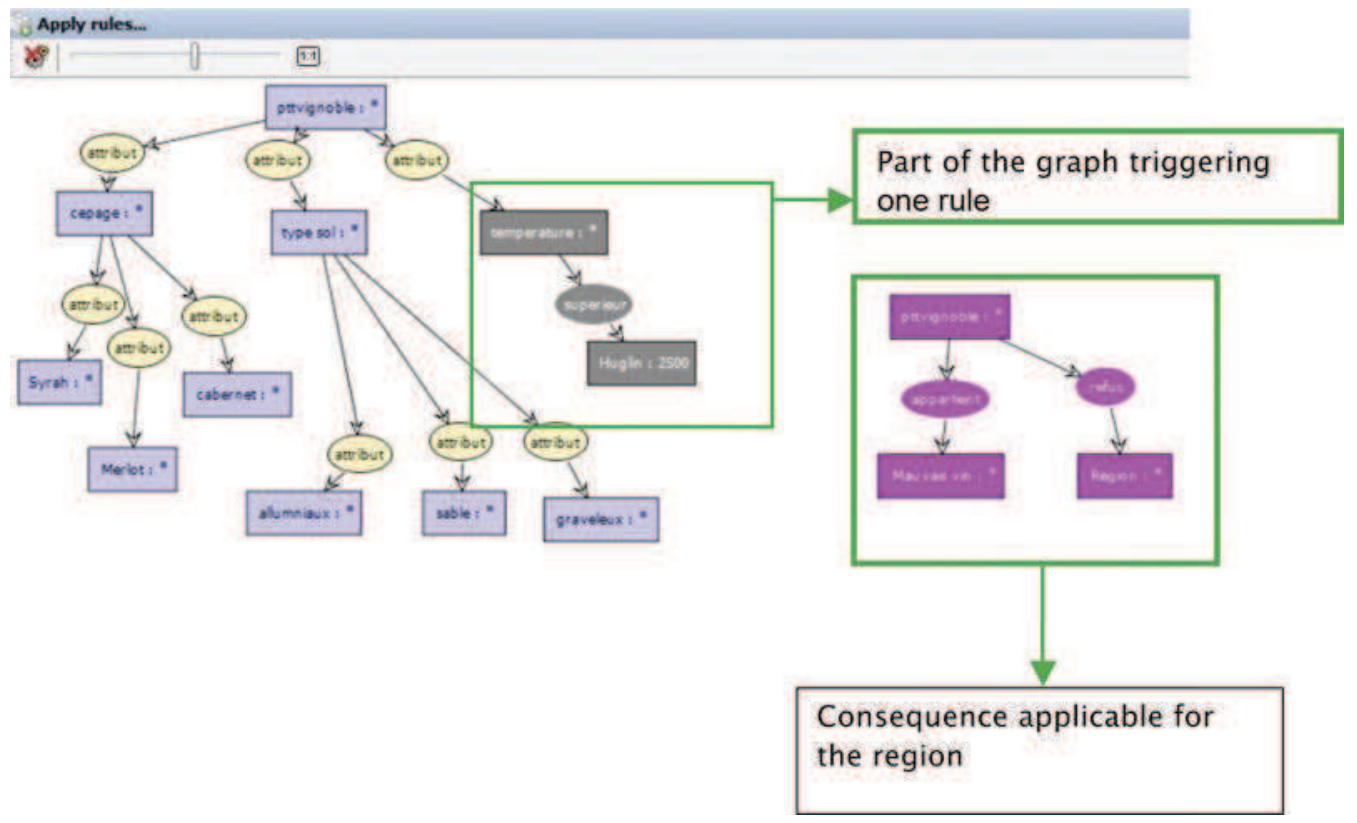

Fig. 8. Analysis of the structure by CoGui.

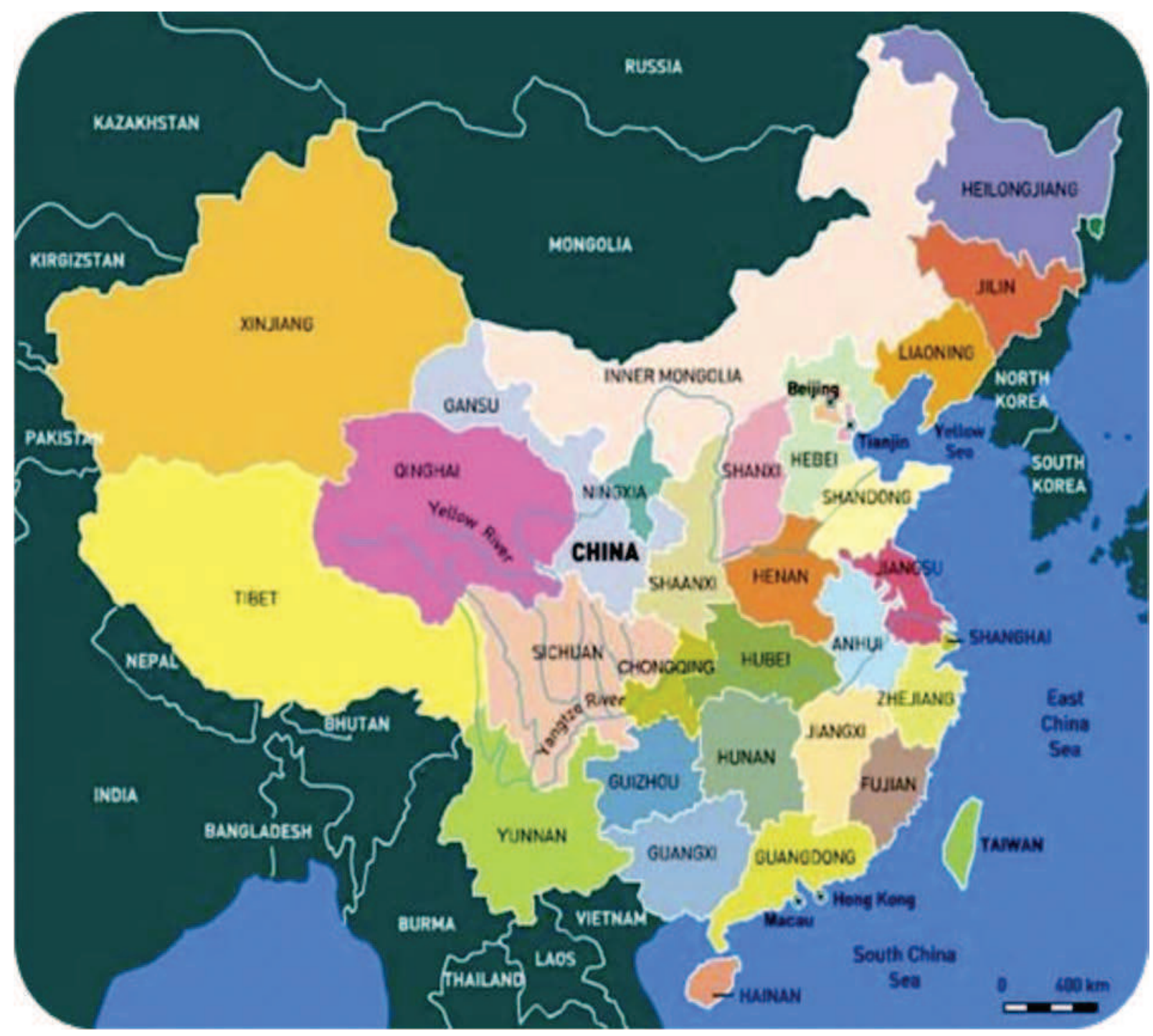

Fig. 9. Wine-growing regions of China. 
rules". The software then displays the graphical structure and visual reasoning, with the difference that it has identified part triggering a rule is in black color and that the consequence part of a rule appears in pink color (Fig. 8).

\section{Implementation analysis of vineyards in China}

At the graphical modeling and visual reasoning, we are able to achieve concrete results through the CoGui software. Indeed we capture some relevant information to model knowledge of vineyards, but also to formalize the rules on driving modes and irrigation systems.

There, we are still able to draw some conclusions to certain regions of China. It appears prominently that two regions seem more favorable and consistent for development of wine from the Bordeaux region (Fig. 9).

- First Xinjiang region, it is compatible both temperatures, with its high Huglin index, and irrigation capacity to compensate for the lack of precipitations. In addition we find a soil composition similar to that present in Bordeaux region, although it must surely be enriched with different elements. Moisture content is an asset for resistance to most diseases, and the desert region limit the presence of insects. The region is prone to sandstorms, driving mode resistant to strong winds; with trellis would be particularly suitable, such as driving by a tying method that leaves a lot of foliage, useful for the maturing process. For irrigation, on use a Karez system that is a traditional way to access water from underground flow that is connected to wells.

- The second region that may correspond to the characteristics of the Bordeaux region is the Gansu. As Xinjiang, its Huglin index allows obtaining high quality of wines. Precipitations are sufficient to not cause water stress too much, and as seen above, a moderate water stress will produce a good quality of the grapes. In addition, its geology, and vines already established show similarities with Bordeaux. The type of sandy and clayey gravelly soil involves poverty in minerals, it is again preferable to analyze these quantities of minerals before fertilize the soil. However, this soil is more conducive to disease development.

- Hebei region, because of its very high Huglin index will be set to work to limit the sunlight of the vines and grapes, for example through a dense driving mode. As part of a new installation, we do not recommend this area as an option to promote.

As regards irrigation on the entire Chinese territory, we will advocate any means not involving a heavy maintenance and technical management. In fact, without questioning the intellectual capacities of the people, for economic reasons investors rely on a workforce unskilled, and this irrigation is misused and have more negative than positive impacts. Combining modeled crop water stress index, soil and climate data improve spatial analysis of terroirs and it enables a better use of environmental features with respect to plant requirement and wine production (Bonfante et al., 2011). Winemaking fermentations aim to adjust the characteristics (temperatures, aromas and flavors properties) of the wine and data mining techniques can be engaged to predict industrial wine problem fermentations (Urtubia et al., 2007). On-line fermentation monitoring, data management and knowledge based systems can assist the winemakers to optimize process performances as well as product quality (Sablayrolles, 2009). Micro-oxygenation in wines can be applied with the aim of bringing about desirable changes in color, aroma and texture (Gómez-Plaza and Cano-López, 2011) (Fig. 10).

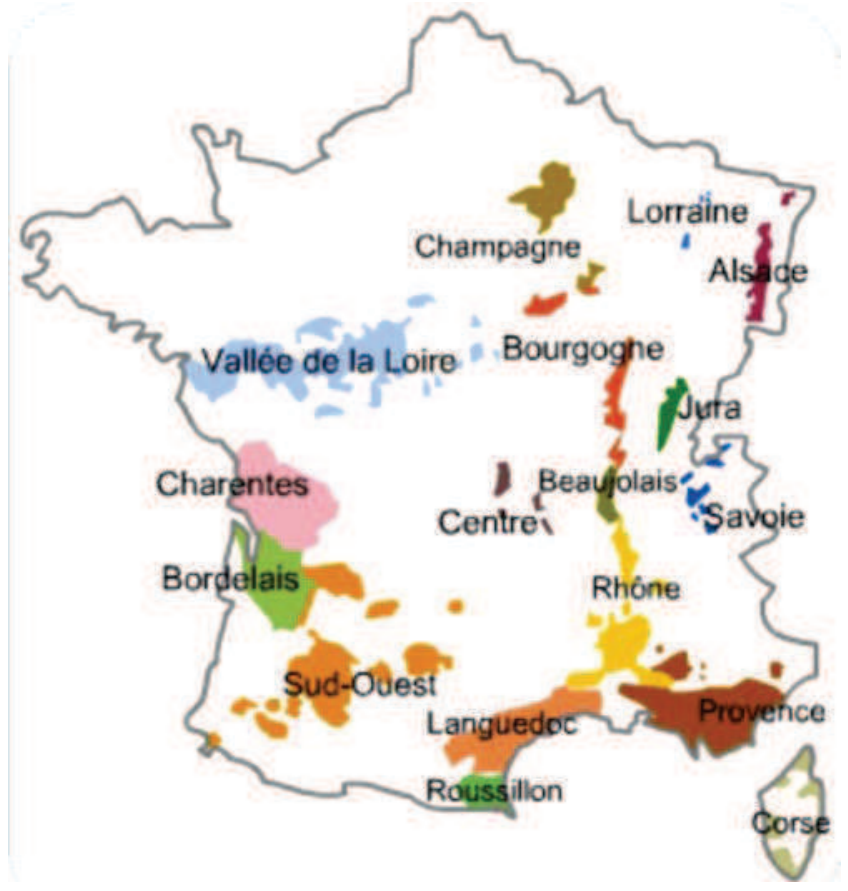

Fig. 10. Wine-growing regions of France.

\section{Conclusion}

This project is a topical issue; we discovered that leading experts in the wine world looked for adapting the implementation of varieties based on geological and climate features. Our work offers services such time as a consultant to determine if an area is suitable for growing vines and what types of parameters are optimized to enable an adequate culture (choice of type of grape, etc.). Our study shows that the viticulture is a complex science that requires detailed knowledge. However simple rules are a good start to avoid falling into common pitfalls. With this report we hope to provide a framework on which the knowledge formalization could take action in support of and to sustain the viticulture process in China. Throughout our study we have found differences between China and France: variances in terms of implementation (meteorological, geological or historical characterizations), culture or treatment of vines to speak only of the influence of human choices (Table 4).

However, our perseverance has enabled us to establish some links between the two countries. Similarly, rather than presenting data in tabular form only, information explaining and analyzing the variances between French viticulture and Chinese viticulture of the control areas are provided in our work in order to allow better analysis of the knowledge and resources requested.

But we are based solely on the study of the quality of the grapes, not in all stages of the winemaking process. Our approach cannot judge the quality of the final wine, this involving many factors, starting with the quality of the winemaker. This would require conducting research and studies on every aspect of wine production from controlling vineyard pests and diseases to developing grapegrowing and winemaking practices to achieve desirable flavors, aromas and mouth-feel in Chinese wines. Data mining techniques would be valuable to support the oenologist wine tasting evaluations and improve wine production by modeling consumer wine taste preferences (Cortez et al., 2009).

In this project we were able to highlight the multitude of factors to consider for the establishment of a vineyard. It is clear that there are many avenues to deepen, and also because the international 
Table 4

Comparative analysis of French and Chinese regions.

\begin{tabular}{|c|c|c|c|c|c|c|c|c|c|c|c|c|}
\hline \multirow[t]{3}{*}{ Wine-growing region } & & \multicolumn{8}{|c|}{ Average temperatures $\left({ }^{\circ} \mathrm{C}\right) /$ precipitations $(\mathrm{mm})$} & \multirow[t]{3}{*}{ Huglin index } & \multirow[t]{3}{*}{ Geology } & \multirow[t]{3}{*}{ Wine varieties } \\
\hline & & \multicolumn{2}{|c|}{ Spring } & \multicolumn{2}{|c|}{ Summer } & \multicolumn{2}{|c|}{ Autumn } & \multicolumn{2}{|c|}{ Winter } & & & \\
\hline & & ${ }^{\circ} \mathrm{C}$ & $\mathrm{mm} / \mathrm{month}$ & ${ }^{\circ} \mathrm{C}$ & $\mathrm{mm} /$ month & ${ }^{\circ} \mathrm{C}$ & $\mathrm{mm} / \mathrm{month}$ & ${ }^{\circ} \mathrm{C}$ & $\mathrm{mm} / \mathrm{month}$ & & & \\
\hline \multirow[t]{4}{*}{ France } & Bordeaux & 15.1 & 75.9 & 19.9 & 68.1 & 10.3 & 102.6 & 7.9 & 81.5 & 2080 & $\begin{array}{l}\text { Clay-limestone and clay-gravel } \\
\text { Palus }\end{array}$ & $\begin{array}{l}\text { Merlot } \\
\text { Cabernet Franc }\end{array}$ \\
\hline & Loire Valley & 14.9 & 44.2 & 19.7 & 25.4 & 9.4 & 37.5 & 7.7 & 56.9 & 1810 & $\begin{array}{l}\text { Boulbènes } \\
\text { Shale - slate - sandstone - }\end{array}$ & $\begin{array}{l}\text { Cabernet sauvignon } \\
\text { Cabernet Franc }\end{array}$ \\
\hline & Loile valley & 14.9 & 44.2 & 19.1 & 20.4 & 9.4 & (7.J & 1.1 & 50.9 & 1010 & freestone -gravels-clay-sand & \\
\hline & Côtes du Rhône & 14.9 & 84.2 & 20.1 & 53.4 & 8.4 & 55.5 & 7.0 & 37.9 & 1850 & $\begin{array}{l}\text { Clay-sand-gravels } \\
\text { Lœss-granite-clay } \\
\text { Limestone sand }\end{array}$ & Syrah \\
\hline \multirow{8}{*}{ China } & Jilin & 13.7 & 50.0 & 19.5 & 116.7 & -2.7 & 13.3 & -9.3 & 3.3 & & & Vitis amurensis \\
\hline & Hebei & 19.3 & 42.0 & 23.4 & 69.0 & 6.4 & 9.0 & -0.4 & 6.0 & 3243 & $\begin{array}{l}\text { Sandy-gravelly } \\
\text { Alluviaux }\end{array}$ & $\begin{array}{l}\text { Syrah } \\
\text { Cabernet } \\
\text { Merlot }\end{array}$ \\
\hline & Bohai Wan & 16.0 & 14.3 & 24.0 & 57.0 & 9.2 & 14.3 & 1.8 & 3.0 & & Sandy hills - limestone & $\begin{array}{l}\text { Chardonnay } \\
\text { Italian Riesling } \\
\text { Cabernets } \\
\text { Merlot } \\
\text { Carignan } \\
\text { Ugni blanc }\end{array}$ \\
\hline & Gansu & 16.8 & 30.7 & 20.7 & 60.7 & 4.2 & 10.0 & 0.7 & 5.0 & 2138 & $\begin{array}{l}\text { Sandy } \\
\text { Clay-limestone }\end{array}$ & $\begin{array}{l}\text { Cabernet sauvignon } \\
\text { Cabernet gernischt } \\
\text { Merlot } \\
\text { Syrah } \\
\text { Cabernet franc } \\
\text { grenache }\end{array}$ \\
\hline & Xinjiang & 16.6 & 3.2 & 21.6 & 2.5 & -1.8 & 1.9 & -9.0 & 1.2 & 2180 & & $\begin{array}{l}\text { Cabernet Sauvignon } \\
\text { Merlot }\end{array}$ \\
\hline & & & & & & & & & & & Sandy & $\begin{array}{l}\text { Chardonnay } \\
\text { Syrah } \\
\text { Pinot noir }\end{array}$ \\
\hline & Yunnan & 13.3 & 48.3 & 17.8 & 130.0 & 5.2 & 17.0 & 2.7 & 13.0 & & Low fertility, rich in quartz & $\begin{array}{l}\text { Merlot } \\
\text { Cabernet Sauvignon } \\
\text { Grenache } \\
\text { Riesling italien } \\
\text { Chardonnay } \\
\text { Yan73 } \\
\text { Rose honey } \\
\text { Jufeng }\end{array}$ \\
\hline & Ningxia & 16.3 & & 20.2 & & 1.9 & & -5.0 & & & & $\begin{array}{l}\text { Cabernet Sauvignon } \\
\text { Cabernet Gernischt } \\
\text { Riesling } \\
\text { Chardonnay }\end{array}$ \\
\hline
\end{tabular}


viticulture is booming (e.g. via its luxury image) and easily find funding for scientific research.

For future works, it would be interesting to build interpretable models in a collaborative manner to make interaction between Artificial Intelligence learning methods and domain experts (Thomopoulos et al., 2013). Examples of interpretable learning models can be made in an iterative way to improve the obtained results (Kamsu-Foguem et al., 2013b). Also, the web-based systems can help non experts in visual identification of some agricultural problems (e.g. plant diseases) (Pertot et al., 2012).

Briefly the conclusion of the China wine regions concerning climates and soils, the conditions to wine growing are not optimal, this means that different types of heavy treatments are needed.

Where irrigation is not required, viticulture could expand and new, higher value crops could be introduced. Moreover we are able to prove that China is a potential good investment for traders and provides some minimal conditions of the vine cycle. Similarly, some companies invest directly in the Chinese territory, since they already get several partnerships with vineyards in the Chinese territory. This view also reminds us that appropriate viticulture situations make it easier to foster economic development.

Then on a history side, we noticed that on the same zone, they were recently planted vines as in Xinjing, we had Chinese trials, China conducted its first atomic test site atmospheric Lop Nor in Xinjiang Autonomous Region Uighur minority, started on October 16,1964 . The last Chinese underground test took place was in July 29,1996 . Originally Tewo County was inhabited by a wide variety of fish, birds, plants and animal species, but it has since become a barren land, Since 2010, the goal to reach by the government is to plant 10,000 acres of vines, a viti-viniculture in conversion. At least in China, at the moment, there is no charter to prove an organic method farming vineyard, a minimum of 4 years is enquire to purify lands if any of this exist one day.

\section{References}

Baget, J.F., Mugnier, M.L., 2002. Extensions of simple conceptual graphs: the complexity of rules and constraints. Journal of Artificial Intelligence Research (JAIR) $16,425-465$

Baget, J.F., Leclère, M., Mugnier, M.L., Salvat, E., 2011. On rules with existential variables: walking the decidability line. Artificial Intelligence 175 (June (9-10)), 1620-1654.

Bonfante, A., Basile, A., Langella, G., Manna, P., Terribile, F., 2011. A physically oriented approach to analysis and mapping of terroirs. Geoderma 167-168 (November), 103-117.

Carloni, O., Leclère, M., Mugnier, M.-L., 2009. Introducing reasoning into an industrial knowledge management tool. Applied Intelligence 31 (3), 211-224.

Charters, S., 2006. Chapter 2 - The history of wine. In: Wine and Society. Elsevier, Butterworth-Heinemann, Oxford (United Kingdom)/Waltham (Massachusetts, United States), pp. 10-45.

Chein, M., Mugnier, M.L., October 2008. Graph-based Knowledge Representation: Computational Foundations of Conceptual Graphs. Series: Advanced Information and Knowledge Processing. Springer, London (United Kingdom), ISBN 978-1-84800-285-2, $445 \mathrm{pp}$.

Cortez, P., Cerdeira, A., Almeida, F., Matos, T., Reis, J., 2009. Modeling wine preferences by data mining from physicochemical properties. Decision Support Systems 47 (November (4)), 547-553.

Ellison, P., Ash, G., McDonald, C., 1998. An expert system for the management of Botrytis cinerea in Australian vineyards. I. Development. Agricultural Systems 56 (February (2)), 185-207.

Fernández-Mar, M.I., Mateos, R., García-Parrilla, M.C., Puertas, B., Cantos-Villar, E., 2012. Bioactive compounds in wine: resveratrol, hydroxytyrosol and melatonin: A review. Food Chemistry 130 (February (4)), 797-813.
Genest, D., Chein, M., 2005. A content-search information retrieval process based on conceptual graphs. Knowledge and Information Systems 8 (3), 292-309 (Springer).

Gómez-Plaza, E., Cano-López, M., 2011. A review on micro-oxygenation of red wines: claims, benefits and the underlying chemistry. Food Chemistry 125 (April (4)), 1131-1140.

González-Álvarez, M., González-Barreiro, C., Cancho-Grande, B., Simal-Gándara, J., 2012. Impact of phytosanitary treatments with fungicides (cyazofamid, famoxadone, mandipropamid and valifenalate) on aroma compounds of Godello white wines. Food Chemistry 131 (April (3)), 826-836.

Hojman, D.E., Hunter-Jones, P., 2012. Wine tourism: Chilean wine regions and routes. Journal of Business Research 65 (January (1)), 13-21.

Huglin, P., Schneider, C., 1998. Biologie et écologie de la vigne (in french). Lavoisier, Paris, $370 \mathrm{pp}$.

Jackson, R.S., 2000. 9 - Specific and Distinctive Wine Styles. Wine Science: Principles, Practice, Perception, second edition. Elsevier, Academic Press, Burlington (Massachusetts, United States)/London (United Kingdom)/San Diego (California, United States), pp. 434-481.

Kamsu-Foguem, B., Tchuenté Foguem, G., Foguem, C., 2013a. Using conceptual graphs for clinical guidelines representation and knowledge visualization. Information Systems Frontiers (ISF), http://dx.doi.org/10.1007/s10796-012-9360-2.

Kamsu-Foguem, B., Rigal, F., Mauget, F., 2013b. Mining association rules for the quality improvement of the production process. Expert Systems with Applications 40 (March (4)), 1034-1045.

Kamsu-Foguem, B., Diallo, G., Foguem, C., 2013c. Conceptual graph-based knowledge representation for supporting reasoning in African traditional medicine. Engineering Applications of Artificial Intelligence (EAAI) 26 (April (4)), 1348-1365.

Kamsu-Foguem, B., 2012. Knowledge-based support in non-destructive testing for health monitoring of aircraft structures. Advanced Engineering Informatics 26 (October (4)), 859-869.

Kamsu Foguem, B., Coudert, T., Béler, C., Geneste, L., 2008. Knowledge formalization in experience feedback processes: an ontology-based approach. Computers in Industry 59 (September (7)), 694-710.

Léger, B., Naud, O., 2009. Experimenting statecharts for multiple experts knowledge elicitation in agriculture. Expert Systems with Applications 36 (October (8)), 11296-11303.

Lockshin, L., Corsi, A.M., 2012. Consumer behaviour for wine 2.0: a review since 2003 and future directions. Wine Economics and Policy 1 (December (1)), 2-23.

De Luca, V., 2011. 4.19 - Wines. Comprehensive Biotechnology, vol. 4., second edition Elsevier, Academic Press, Burlington (Massachusetts, United States)/London (United Kingdom)/San Diego (California, United States), pp. 241-255.

Nicholas, K.A., Durham, W.H. 2012. Farm-scale adaptation and vulnerability to environmental stresses: insights from winegrowing in Northern California. Global Environmental Change 22 (May (2)), 483-494.

Paoli, J.-N., Strauss, O., Tisseyre, B., Roger, J.-M., Guillaume, S., 2007. Spatial data fusion for qualitative estimation of fuzzy request zones: application on precision viticulture. Fuzzy Sets and Systems 158 (March (5)), 535-554.

Papadimitriou, F., 2012. Artificial intelligence in modelling the complexity of Mediterranean landscape transformations. Computers and Electronics in Agriculture 81 (February), 87-96.

Pertot, I., Kuflik, T., Gordon, I., Freeman, S., Elad, Y., 2012. Identificator: a web-based tool for visual plant disease identification, a proof of concept with a case study on strawberry. Computers and Electronics in Agriculture 84 (June), 144-154.

Ripoche, A., Rellier, J.-P., Martin-Clouaire, R., Paré, N., Biarnès, A., Gary, C., 2011. Modelling adaptive management of intercropping in vineyards to satisfy agronomic and environmental performances under Mediterranean climate. Environmental Modelling \& Software 26 (December (12)). 1467-1480.

Sablayrolles, J.M., 2009. Control of alcoholic fermentation in winemaking: current situation and prospect. Food Research International 42 (May (4)), 418-424.

Sowa, J., 1984. Conceptual Structures: Information Processing in Mind and Machine. The Systems Programming Series (Hardcover). Addison-Wesley Longman Publishing Co., Inc., Boston, MA, USA, 481 pp.

Sowa, J.F., 2000. Knowledge Representation: Logical, Philosophical and Computational Foundations. Brooks/Cole, Pacific Grove (California, United States).

Thomopoulos, R., Destercke, S., Charnomordic, B., Johnson, I., Abécassis, J., 2013. An iterative approach to build relevant ontology-aware data-driven models. Information Sciences 221 (February), 452-472.

Tonietto, J., Carbonneau, A., 2004. A multicriteria climatic classification system for grape-growing regions worldwide. Agricultural and Forest Meteorology 124 (1-2), 81-97.

Urtubia, A., Ricardo Pérez-Correa, J., Soto, A., Pszczólkowski, P., 2007. Using data mining techniques to predict industrial wine problem fermentations. Food Control 18 (December (12)), 1512-1517. 